DOE/EIA-M054

prarings

SFP 271999

OS 11

\title{
Motor Gasoline Market Model Documentation Report
}

September 1993

\author{
Energy Information Administration \\ Office of Oil and Gas \\ U.S. Department of Energy \\ Washington, DC 20585
}




\title{
Motor Gasoline Market Model Documentation Report
}

\section{INTRODUCTION}

\section{Purpose of the Report}

The purpose of this report is to define the objectives of the Motor Gasoline Market Model (MGMM), describe its basic approach and to provide detail on model functions. This report is intended as a reference document for model analysts, users, and the general public. Documentation of the model is in accordance with EIA's legal obligation to provide adequate documentation in support of its models (Public Law 94-385, Section 57(b)(2)).

\section{Model Summary}

The MGMM performs a short-term (6- to 9-month) forecast of demand and price for motor gasoline in the U.S. market; it also calculates end of month stock levels. The model is used to analyze certain market behavior assumptions or shocks and to determine the effect on market price, demand and stock level.

\section{Model Archival Citation}

The Motor Gasoline Market Model (MGMM) is archived on IBM-compatible floppy disks and is available through the sponsoring office. The model contact is:

\author{
Dr. Charles Dale \\ U.S. Department of Energy \\ Energy Information Administration \\ Office of Oil and Gas \\ Petroleum Marketing Division \\ Publications and Analysis Branch \\ Mail Code: El-432 \\ Forrestal Bldg \\ Room 2(j-029 \\ 1000 Independence Ave. SW \\ Washington, DC 20585 \\ (202) $586-1805$
}

\section{Report Organization}

The remainder of this report is organized in the following manner: (1) model purpose, (2) model rationale, (3) model structure, (4) properties of mathematical solution, (5) calibration and sensitivity analysis, (6) documentation of technical detail on model data and equations, and (7) appendices. 


\section{MODEL PURPOSE}

\section{Model Objectives}

The MGMM is to be used for policy analysis and general forecasting purposes and was developed for use in the Motor Gasoline Outlook article published in the Petroleum Marketing Monthly. The model addresses very short-term monthly U.S. market responses at the national level. The model focuses on U.S. retail motor gasoline demand and price, and assesses market response to alternative scenarios and/or shocks by providing very short-term (up to 9-month) forecasts of gasoline demand and price. The model relies on the Short-Term Energy Outlook (STEO) mid world oil price case to define a baseline and then uses assumptions on different possible market disturbances to assess market response on a monthly basis; the MGMM differs from STEO because of the provision for monthly, rather than quarterly, predictions. It has been used to forecast the effect of crude price changes or increased demand on gasoline prices and product supplied. The MGMM also provides a framework to calculate stock levels from the forecasted demand and price variables.

\section{Model Input/Output}

The MGMM uses both DOE and non-DOE data input sources. The non-DOE data came from two sources. Data Resources Inc. (DRI) databases provided values, from the Bureau of Economic Analysis and the Bureau of Labor statistics, for general macroeconomic variables (including personal income, producer and consumer price indices, industrial production index) and gasoline price. The Federal Highway Administration was the source for vehicle miles traveled. The DOE data for crude oil prices, refinery variables, motor gasoline demand, stock levels and net imports came from EIA publications: the Petroleum Marketing Annual/Monthly and the Petroleum Supply Annual/Monthly. All forecasts for future values of the independent variables used in the MGMM came from EIA's Short-Term Integrated Forecasting System (Energy Information Administration, 1990)

Output from the MGMM includes very short-term monthly forecasts of national U.S. demand, price and stock levels of total retail motor gasoline.

\section{Relationship to Other Models}

The MGMM does not directly interface with other models; however, it does utilize forecasts of certain macroeconomic and refinery variables from the Short-Term Integrated Forecasting System (STIFS) as inputs

\section{MODEL OVERVIEW AND RATIONALE}

\section{Fundamental Assumptions}

The MGMM is to be used to judge the effect of shocks or alternative behavior assumptions on the demand, price and end of month stock level for retail motor gasoline in the rational economy. The theoretical basis for the model is the standard demand-supply approach used to determine the market effects of shifting demand and supply curves on a single product in an isolated market; it implicitly makes the assumption that all economic entities exhibit profit maximizing behavior. The model allows for feedback effects between price and demand over a monthly time frame. Although the model functions at a monthly frequency, conclusions are normally drawn from the model on a quarterly or semi-annual basis. The MCiMM uses recent historical market behavior as a pattern for predicting near-term future market responses. 
The MGMM is concerned with very shert-term (i.e., 6- to 9-month) projections into the future. In order to make the analysis more tractable, a number of simplifying assumptions were made concerning the behavior of the motor gasoline market: these include

- Constant automobile efficiency. Automobile efficiency is an important determinant of the long-run demand for gasoline. but is relatively constant in the short-run due to the slow replacement of the current automobile fleet.

- The motor gasoline market is isolated from disturbances to other petroleum product markets. It is assumed that any significant interaction between the gasoline market and other product markets would not occur within the time frame of the forecast.

- Constant level of taxation. Taxes on retail gasoline have a direct effect on price and an indirect effect on demand. For the time frame of the forecast, it is assumed that any increased taxation is expected to be small enough so that the impact on the gasoline market is negligible.

The model makes no provision to distinguish between the types (e.g., clear, oxygenated, reformulated) or grade (e.g., regular, mid-grade, premium, etc.) of motor gasoline sold on the retail market. The model also utilizes the concept of total motor gasoline end of month stocks, which consists of the sum of the stock levels of finished gasoline and gasoline blending components.

The MGMM allows market players to make pricing decisions based on historical stock patterns. This behavior pattern shows up in the price equation, which includes a number of lags for two types of stock level variables: month to month stock changes and deviations from the average stock level. The model assumes that market players make decisions on a monthly basis; although this may be somewhat of a long reference time frame, any analysis utilizing a more rapid decision making process is hampered by the lack of data availability at higher frequencies.

\section{Alternative Approaches}

The MGMM is a time series model typical of a form for the estimation of gasoline demand (see, for example, C. Dahl and T. Sterner, 1991). Cross-sectional models were not considered because of the need to forecast market adjustments to possible shocks for more than a single time period. The STIFS model formulation was not used because of the desire to utilize motor gasoline imports as a variable internal to the model.

Prof. Tim Considine of Pennsylvania State University recently developed a short-term forecasting model for ElA (Task No. 92073, Contract No. DE-AC01-89-EI21003). That model was not used here for several reasons:

- The desire to model the gasoline market as an isolated sector of the economy.

- The desire to avoid the problem of nonconvergence that can occur in multi-product models.

- The desire to estimate product supplied (demand) directly, rather than as an identity, in order to check the model's prediction of consumer behavior.

- The desire to focus on retail motor gasoline prices rather than the wholesale prices contained in a production oriented model

\section{MODEL STRUCTURE}

\section{Flow Diagram}


MOTOR GASOLIXE MARKET MODEL PLOW DIAGRAM

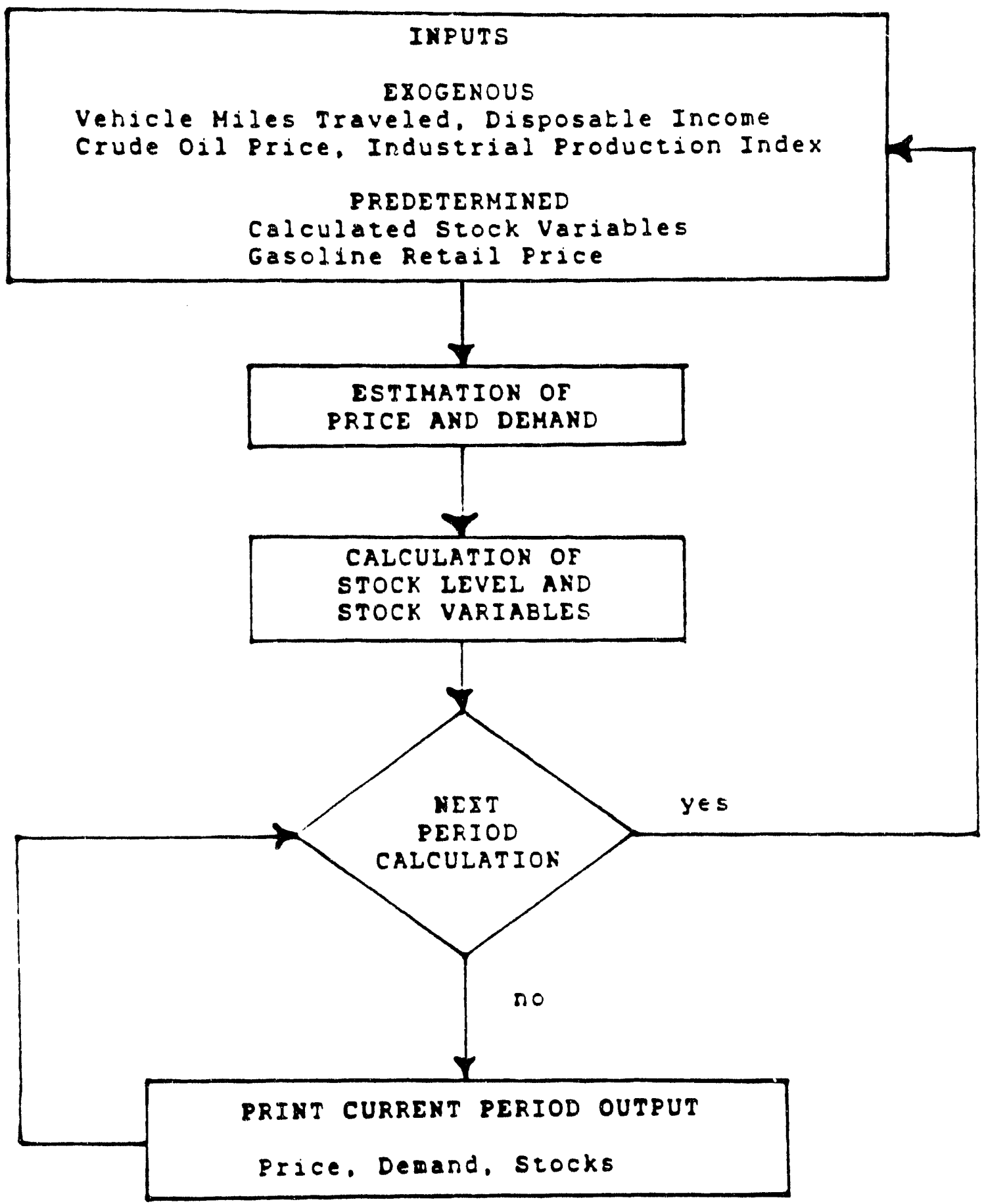


Solution of the MGMM proceeds in a straightforward manner. The input variables are used as the independent variables for the estimation of price, and this price is then used along with other inputs to estimated demand. The model then algebraically calculates the projected stock level (and other stock related variables used as inputs). The current period solution is printed and the model proceeds (if necessary) to the estimation for the next period.

\section{iist of Computations and Equations}

The equation used by the model for the estimation of price is of the form:

PRICE $=$ (VMT, current and lagged RAC87, lags of STOCKDEL, lags of STKCHNG, lagged PRICE).

The actual estimated price equation is:

$$
\begin{aligned}
& \text { PRICE }_{t}=\quad \alpha_{0}+\alpha_{1}^{*} \text { VMT }_{t}+\alpha_{2}^{*} \text { RAC87, }_{1}+\alpha_{3}^{*} \text { RAC87 }_{t-1}+\alpha_{4}^{*} \text { STOCKDEL }_{t-1} \\
& +\alpha_{s} * \operatorname{STOCKDEL}_{1-2}+\alpha_{6} * \operatorname{STOCKDEL}_{t-3}+\alpha_{7} * \text { STOCKDEL }_{t-4} \\
& +\alpha_{8}{ }^{*} \mathrm{STKCHNG}_{t-1}+\alpha_{9}{ }^{*} \mathrm{STKCHNG}_{1-2}+\alpha_{10}{ }^{*} \mathrm{STKCHNG}_{\mathrm{t}-3} \\
& +\alpha_{11}^{*} \text { PRICE }
\end{aligned}
$$

The equation used by the model for the estimation of demand (product supplied) is of the form:

DEMAND $=\quad$ (Industrial Production Index, Price, Disposable Income, monthly dummy variables)

The actual estimated demand equation is:

$$
\text { DEMAND }_{1}=\beta_{0}+\beta_{12}^{*} \mathrm{IPI}_{\mathrm{t}}+\beta_{13}^{*} \mathrm{PRIC}_{\mathrm{t}}+\beta_{14} * \mathrm{YD}_{\mathrm{t}}+\sum_{1=\mathrm{T}}^{11} \beta_{\mathrm{i}}^{*} \mathrm{DUMMY}
$$

where PRICE is the average retail price of motor gasoline deflated by the CPI.

$\mathrm{PI} \quad$ is the consumer price index

VMT is vehicle miles traveled (on a daily basis)

RAC87 is the aver-ge crude oil refiners acquisition cost deflated by the PPI

PPI is the producer price index $(1987=$ reference year)

STOC'KDEL. is the relative deviation of the current stock level from the average of the previous 3 years

STKCHNG is the stock level change from the previous month

DEMANI) is the finished motor gasoline product supplied

IPI is the industrial production index

YD is the red disposable personal income

I)ISMMY, are monthly dummy variables

1 is the subseript variable for monthly time series observations 
VMT is used in the price equation as a direct indication of total demand for motor gasoline for all sectors of the 11.5 economy. In contrast, IPI is used in the demand equation because it represents the effect of increased use of transportation iuels to move goods to markets.

The inputs to the above equations are exogenous (i.e. STLO estimated) or previously calculated values for the variables Output consists of one month ahead forecasts of PRICE and DEMAND for motor gasoline. The determination of the one month ahead stock level from the forecasted level of demand is calculated by the following formulas:

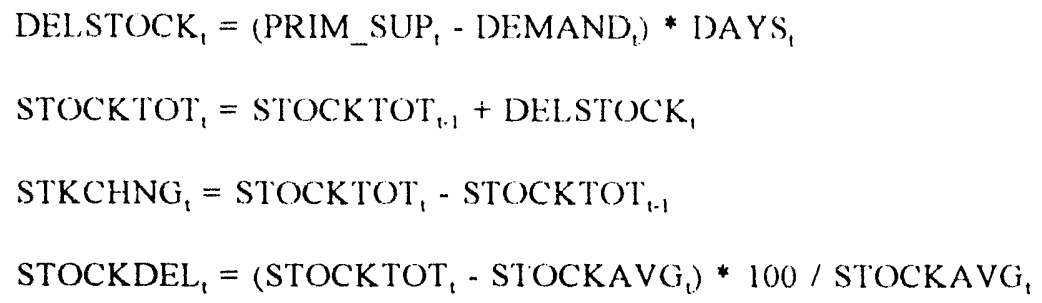

where PRIM_SUP is the sum of refinery output and net imports of motor gasoline

DAYS is the number of days in month $t$

STOCKAVG' is $\left(\text { STOCKTOT }_{1-12}+\text { STOCKTOT }_{1-24}+\text { STOCKTOT }_{1-36}\right)^{\prime} 3$

(Note: the formulas used to calculate stock levels may differ slightly from those illustrated above for alternative scenarios: by the inclusion of equations to calculate a demand increase or equations to calculate the increased amount of imports.)

\section{PROPERTIES OF MATHEMATICAL SOLUTION}

\section{Theoretical Considerations}

The model is a standard demand-supply system of "simultaneous" equations. The problem of simultaneous equations bias was addressed by formulating the model as a system of recursive equations with unidirectional dependency among the dependent variables. The first endogenous variable, viz. price, is determined only by exogenous (and predetermined) variables; the second endogenous variable, viz. demand, is determined only by exogenous variables and the endogenous price variable. There is no direct feedback from demand back to price, so that if there is a disturbance to the demand equation, it does not affect the price equation. Thus there is no contemporaneous correlation between the demand equation and price, so that Ordinary Least Square (OL.S) estimate is consistent. OL.S is not unbiased, however, because of the presence of a lagged dependent variable ( $P$. Kennedy, 1985).

Certain a priori restrictions were placed on the domain of a number of variables. These include

- The lag-one autocorrelation parameter of the model has a domain between -1 and +1 .

- The elasticity of demand is between 0 and -1 , the elasticity of supply is greater than zero;

- Tne price, demand and stock level are greater than zero. 


\section{Subject-Matter Considerations}

The MGMM is applicable to a market for retail motor gasoline unaffected to any major degree by the Clean Air Act Amendments of 1990 because the model does not specifically allow for the effects of oxygenated and reformulated fuels on the retail gasoline market. The MGMM assumes that market reactions are based on recent historical patterns and that any behavioral effects due to increased market segmentation as a result of the introduction of these ruels will be incremental. While the annual incorporation of current data with historical trends may tend to reduce MGMM's responsiveness, minor structural changes in the market can be accommodated with modifications to the equations. The domain of the input variables is assumed to be that of the recent historical time series for ihe individual variables. 


\section{Results of Calibration}

Calibration of the model was performed using a comparison of the forecasts for demand, price and end of month stock level obtained by the MGMM with those obtained by STIFS for March through September, 1993. The following three tables illustrate the comparison values. It should be noted that the values for the first two months reported in the tables are actual, rather than forecasted, values.

MOTOR GASOLINE OUTLOOK: DEMAND

Comparison of STEO and MGMM forecasts

\begin{tabular}{|c|c|c|}
\hline DATE & $\begin{array}{c}\text { STEO } \\
\text { (MMbbl/d) }\end{array}$ & $\begin{array}{c}\text { MGMM } \\
(\mathrm{MMbbl} / \mathrm{d})\end{array}$ \\
\hline Jan-93 & 6876 & 6876 \\
\hline Feb-93 & 7088 & 7088 \\
\hline Mar-93 & 7285 & 7281 \\
\hline Apr-93 & 7184 & 7279 \\
\hline May-93 & 7394 & 7420 \\
\hline Jun-93 & 7543 & 7653 \\
\hline Jul-93 & 7601 & 7554 \\
\hline Aug-93 & 7635 & 7617 \\
\hline Sep-93 & 7285 & 7249 \\
\hline
\end{tabular}


MOTOR GASOLINE OUTLOOK: STOCKS

Comparison of STEO and MGMM forecasts

\begin{tabular}{|c|c|c|}
\hline DATE & $\begin{array}{c}\text { STEO } \\
(\text { M:Mbbl })\end{array}$ & $\begin{array}{c}\text { MGMM } \\
(\mathrm{MMbb})\end{array}$ \\
\hline Jan-93 & 234.0 & 234.0 \\
\hline Feb-93 & 238.5 & 238.5 \\
\hline Mar-93 & 224.5 & 226.3 \\
\hline Apr-93 & 221.0 & 221.0 \\
\hline May-93 & 220.4 & 220.3 \\
\hline Jun-93 & 219.4 & 216.7 \\
\hline Jul-93 & 216.0 & 215.1 \\
\hline Aug-93 & 210.6 & 209.4 \\
\hline Sep-93 & 215.4 & 214.6 \\
\hline
\end{tabular}

MOTOR GASOLINE OUTLOOK: PRICE

Comparison of STEO and MGMM forecasts

\begin{tabular}{|c|c|c||}
\hline DATE & $\begin{array}{c}\text { STEO } \\
\text { (cents/gal) }\end{array}$ & $\begin{array}{c}\text { MGMM } \\
\text { (cents/gal) }\end{array}$ \\
\hline \hline Jan-93 & 118.2 & 118.2 \\
\hline Feb-93 & 117.2 & 117.2 \\
\hline Mar-93 & 116.1 & 116.9 \\
\hline Apr-93 & 119.5 & 120.4 \\
\hline May-93 & 123.2 & 123.8 \\
\hline Jun-93 & 125.2 & 124.3 \\
\hline Jul-93 & 124.9 & 124.8 \\
\hline Aug-93 & 124.6 & 126.4 \\
\hline Sep-93 & 123.9 & 126.7 \\
\hline
\end{tabular}


Another calibration was performed by using the MGMM to backeast motor gasoline price and demand for the previous two quarters (1.e., 1992Q4 and 1993Q1). The results are shown in the next two tables, along with the actual values and the STIFS projections for the same time period. It can be seen that the accuracy of the MGMM values compare quite favorably to those generated by STIFS

MOTOR GASOLINE BACKCAST: PRICE

Comparison of Model Predictions with Actual Values

(Cents per Gallon)

\begin{tabular}{|c|c|c|c|c||}
\hline \hline DATE & SERIES & ACTUAL & MGMM & STEU \\
\hline $\begin{array}{c}\text { 4th Quarter, } \\
1992\end{array}$ & value & 121.4 & 121.0 & 126 \\
\hline $\begin{array}{c}\text { 1st Quarter, } \\
1993\end{array}$ & value & 117.2 & 114.5 & 120 \\
\hline
\end{tabular}

MOTOR GASOLINE BACKCAST: DEMAND

Comparison of Model Predictions with Actual Values

(Million Barrels per Day)

\begin{tabular}{|c|c|c|c|c||}
\hline DATE & VALUE & ACTUAL & MGMM & STEO \\
\hline 4th Quarter, 1992 & Actual & 7.28 & 7.22 & 7.20 \\
\hline & Deviation from Actual & & +0.06 & +0.08 \\
\hline 1st Quarter, 1993 & Actual & 7.08 & 7.05 & 7.02 \\
\hline & Deviation from Actual & & +0.03 & +0.06 \\
\hline
\end{tabular}

\section{Model Runs to Test Concordance with Intuition}

The MGMM underwent two tests to determine its correspondence with intuition and economic theory. The first test was used to determine price behavior in the market when the price of a critical input was increased the reliners cost of crude oil was increased by $\$ 5.00$ a barrel in the month of July for one period. In this case the model predicts that the market price will rapidly increase by 50 percent of the increase in input price, and that the market price will gradually return, over a period of three months, back to the base case level. Historical observations of recent market behavior as a result of similar disturbances has shown that the retail price will rapidly increase and then return to normal after a period of (wo or three months (see, for example, J. Cook and C. Shirkey, 1989). 
The second test increased market demand for motor gasoline during the summer driving season, beginning in the month of April. Economic theory suggests that with constant supply, the market price should increase. For this case, in order to simulate supplier response to the increase in demand, refinery production was assumed to increase up to the maximum sustainable output level. It is important to note that this assumption results in an increase in product supplied, thus tending to moderate market price fluctuations. The MCiMM predicts that the market price will begin to rise faster than the base case approximately two months after the start of the demand increase (i.e., the point in time where the increased demand outstrips the increased production) and that the retail price will rise about 1.5 cents above the base case.

The following tables show the MGMM's hehavior under these scenarios and demonstrates the models concordance with intuition. It should be also noted that a feedback mechanism exists between price and demand: an increase in price will decrease quantity demanded.

MOTOR GASOLINE SCENARIOS: DEMAND

Impact of Alternative Scenario Assumptions

(Thousand Barrels per Day)

\begin{tabular}{|c|c|c|c|}
\hline DATE & BASE CASE & $\begin{array}{c}\text { CRUDE PRICE } \\
\text { SPIKE }\end{array}$ & $\begin{array}{c}\text { DEMAND } \\
\text { INCREASE }\end{array}$ \\
\hline Jan-93 & 6876 & 6876 & 6876 \\
\hline Feb-93 & 7088 & 7088 & 7088 \\
\hline Mar-93 & 7281 & 7281 & 7281 \\
\hline Apr-93 & 7279 & 7279 & 7423 \\
\hline May-93 & 7420 & 7420 & 7567 \\
\hline Jun-93 & 7653 & 7653 & 7807 \\
\hline Jul-93 & 7554 & 7514 & 7703 \\
\hline Aug-93 & 7617 & 7587 & 7762 \\
\hline Sep-93 & 7249 & 7242 & 7383 \\
\hline
\end{tabular}


MOTOR GASOLINE SCENARIOS: PRICE

Impact of Alternative Scenario Assumptions

(Cents per Gallon)

\begin{tabular}{|c|c|c|c||}
\hline DATE & BASE CASE & $\begin{array}{c}\text { CRUDE PRICE } \\
\text { SPIKE }\end{array}$ & $\begin{array}{c}\text { DEMAND } \\
\text { INCREASE }\end{array}$ \\
\hline Jan-93 & 118.2 & 118.2 & 118.2 \\
\hline Feb-93 & 117.2 & 117.2 & 117.2 \\
\hline Mar-93 & 116.9 & 116.9 & 116.9 \\
\hline Apr-93 & 120.4 & 120.4 & 120.7 \\
\hline May-93 & 123.8 & 123.8 & 124.0 \\
\hline Jun-93 & 124.3 & 124.3 & 124.2 \\
\hline Jul-93 & 124.8 & 130.9 & 125.1 \\
\hline Aug-93 & 126.4 & 130.9 & 127.5 \\
\hline Sep-93 & 126.7 & 127.8 & 128.4 \\
\hline
\end{tabular}

\section{DCCUMENTATION OF TECHNICAL DETAIL ON MODEL DATA AND EQUATIONS}

\section{Validation of Input Date}

Input variables which the MGMM has in common with the STIFS were used with exactly identical values. The only case where the STIFS inputs differ with those in general publication is Disposable Income, where a smoothed time series is used for dates after December, 1990

\section{Non-DOE Input Sources:}

Data Resources Inc. (DRI) database, data from Bureau of Economic Analysis and Bureau of Labor Statistics

- Macroecnnomic production, price indices, personal income, retail price of motor gasoline

Federal Highway Administration, Traffic Volume Trends, various issues.

Vehicle miles traveled. 


\section{DOE Data Input Sources:}

\section{Forms and Publications:}

Energy Information Administration. Petroleum Supply Annual, D) ()F/EIA-(1)340 and Petroleum Supply Monthly DOE/EIA-0109

- Finished motor gasoline and blending component stocks

Energy I.tormation Administration, Petroleum Marketing Annual, DOE/LiA-0487 and Petroleum Marketing Monthly. DOE/EIA-(0380.

- Average Crude Oil Refiner's Acquisition Costs

\section{Models and Other:}

Energy Information Administration, Short-Term Integrated Forecasting System.

- Forecasts of economic and refinery variables.

\section{Validation, Goodness-of-Fit of Equations Providing Parameter Estimates}

The next table details the parameter estimates and a number of statistics related to the goodness-of-fit of the equations estimated by the MGMM 


\section{REGRESSION RESULTS}

Dependent Variable is PRICE

SAMPLE RANGE: $1987.01-1992.12$

Number of Observations: 72

Convergence achieved after 5 iterations

\begin{tabular}{||c|c|c|c|c||}
\hline VARIABLE & COEFFICIENT & STD. IERROR & T-STAT & Prob>|T| \\
\hline C & 25.512620 & 7.6154205 & 3.3501 & 0.0014 \\
\hline VMT & 0.0017530 & 0.0006545 & 2.6785 & 0.0096 \\
\hline RAC87 & 0.9951925 & 0.1609093 & 6.1848 & 0.0000 \\
\hline RAC87(-1) & 0.4645073 & 0.2592152 & 1.7920 & 0.0783 \\
\hline STOCKDEL(-1) & 0.0358770 & 0.0612970 & 0.5853 & 0.5606 \\
\hline STOCKDEL(-2) & -0.0653890 & 0.0616695 & -1.0603 & 0.2933 \\
\hline STOCKDEL(-3) & -0.0887065 & 0.0652391 & -1.3597 & $0.179 i$ \\
\hline STOCKDEL(-4) & -0.1975904 & 0.0667848 & -2.9586 & 0.0044 \\
\hline STKCHNG(-1) & $-8.781 \mathrm{E}-05$ & $2.020 \mathrm{E}-05$ & -4.3482 & 0.0001 \\
\hline STKCHNG(-2) & -0.0001208 & $2.421 \mathrm{E}-05$ & -4.9908 & 0.0000 \\
\hline STKCHNG(-3) & $-4.329 \mathrm{E}-05$ & $2.335 \mathrm{E}-05$ & -1.8543 & 0.0687 \\
\hline PRICE(-1) & 0.3039848 & 0.1097809 & 2.7690 & 0.0075 \\
\hline A r.-(1) & 0.6771744 & 0.1261146 & 5.3695 & 0.0000 \\
\hline \hline R-squared & & 0.96465 & Mean of dependent var & 86.0783 \\
\hline Adjusted R-squared & & 0.95747 & Sum of squared resid & 91.4534 \\
\hline S.E. of regression & 1.24501 & F-statistic & & 134.185 \\
\hline Durbin h statistic & -0.552 & Prob(F-statistic) & & 0.00000 \\
\hline
\end{tabular}


Dependent Variable is IDEMAND

SAMPLEE RANGil 1987.(11 - 1992.!2

Number of Observations: 72

convergence achieved after 4 iterations

\begin{tabular}{|c|c|c|c|c|}
\hline VARIABLE & COEFFICIENT & STD ERROR & T-STAT & Prob $>|T|$ \\
\hline $\mathrm{C}$ & 6941.711 .38 & 38940948 & 17.8262 & 0.0000 \\
\hline IPI & 3721.4633 & 789.01361 & 4.7166 & 0.0000 \\
\hline PRICE & -9.25672 & 2.040027 & -4.5376 & 0.0000 \\
\hline YD & -0.98367 & 0.265291 & -3.7079 & 0.0005 \\
\hline $\mathrm{FEB}$ & 309.38345 & 82.930074 & 3.7307 & 0.0004 \\
\hline MAR & 505.57559 & 68.630882 & 7.3666 & 0.0000 \\
\hline APR & 517.78614 & 73.899673 & 7.0066 & 0.0000 \\
\hline MAY & 678.14555 & 72.463970 & 9.3584 & 0.0000 \\
\hline IUN & 898.16335 & 73.378776 & 12.2401 & 0.0000 \\
\hline JUL & 785.08370 & 73.695955 & 10.6530 & 0.0000 \\
\hline AUG & 846.95524 & 74.206175 & 11.4135 & 0.0000 \\
\hline SEP & 488.00825 & 73.944575 & 6.5996 & 0.0000 \\
\hline OCT & 592.07532 & 74.848870 & 7.9103 & 0.0000 \\
\hline NOV & 507.66135 & 70.089247 & $7.243 i$ & 0.0000 \\
\hline DEC & 579.25487 & 83.429762 & 6.9430 & 0.0000 \\
\hline $\operatorname{AR}(1)$ & -0.31643 & 0.127801 & -2.4760 & 0.0163 \\
\hline R-squared & 0.85097 & \multicolumn{2}{|c|}{ Mean of dependent var } & 7259.10 \\
\hline Adjusted R-squared & 0.81106 & \multicolumn{2}{|c|}{ Sum of squared resid } & 782795 \\
\hline S.E of regression & 118.231 & \multicolumn{2}{|l|}{ F-statistic } & 21.3180 \\
\hline Durbin-Watson stat & 2.13557 & \multicolumn{2}{|c|}{$\operatorname{Prob}($ F-statistic $)$} & 0.00000 \\
\hline
\end{tabular}




\section{APPENDICES}

\section{BIBLIOGRAPHY}

J. Cook and C. Shirkey, "A Review of Valdez. Oil Market Impacts," Petroleum Marketing Monthly, DOE/EIA-0380 (89/03), March 1989, pp. 5-14.

C. Dahl and T. Sterner, "A Survey of Econometric Gasoline Demand Elasticities," International Journal of Energy Systems, Vol. 11, No. 2, 1991, pp. 73-86.

Energy Information Administration, Short-Term Integrated Forecasting System, 1990 Model Documentation Report, DOE/EIA-M04 1, 1990, Washington, DC.

P. Kennedy, A Guide To Econometrics, 2nd Edition, MIT Press, Cambridge, Massachusetts, 1985. 


\section{Model Abstract}

Model Name: Motor Gasoline Market Model

Model Acronym: MGMM

Model Description: The MGMM performs a short-term (6-to 9-month) forecast of demand and price in the U.S. motor gasoline market. The model also calculates the end of month stock level. The model is used to analyze certain market behavior assumptions or market shocks and to determine their effect on market price, demand and stocks.

Last Model Update: April, 1993

Part of Another Model: None

Model Interfaces: None. The MGMM uses inputs from STIFS, from which it obtains Economic and Refinery Data.

\section{Sponsor:}

Office: Office of Oil and Gas.

Division: Petroleum Marketing Division.

Branch: Publications and Analysis, EI-432

Model Contact: Charles Dale

Telephone: (202) 586-1805

Documentation: Energy Information Administration. Model Documentation of the Motor Gasoline Market Model, DOE/EIA-M***, (Washington, DC, May 1993).

Archive Media and Installation Guides: Archived on floppy disks, with internal documentation. Available from sponsoring office. Archive packages describing the use of the model in published applications may be obtained from

National Technical Information Service

5285 Port Royal Road

Springfield, Virginia 22161

Purpose: The Motor (iasoline Market Model ua developed to provide support for the "Motor (iasoline Outlook" article published in the petroleum Marketing Monthly. The MCiMM assesses the market response to alternative market scenarios and/or shocks. The model relies on the STIFS mid world oil price case for values of economic and refinery behavior variables to define a base-line and then uses assumptions on different possible market disturbances to assess their effects 
on a monthly basis. The MGMM provides a framework to calculate stock levels from the estimated demand and price variables.

Energy System Described by Model: Motor gasoline demand and prices.

\section{Coverage:}

Geographic: National.

Time Unit/Frequency: Monthly.

Products: Motor Gasoline.

Economic Sector: Retail Motor Gasoline Market.

\section{Modeling Features:}

Model Structure: Recursive multi-equation model.

Modeling Technique: Ordinary least squares, with correction for autucorrelation.

Special Features: None.

\section{Non-DOE Input Sources:}

Data Resources Inc. (DRI) database, data from Bureau of Economic Analysis and Bureau of Labor Statistics.

- Macroeconomic production, price and income variables, retail price of motor gasoline.

Federal Highway Administration, Traffic Volume Trends, various issues.

- Vehicle miles traveled.

DOE Data Input Sources:

Forms and Publications:

Energy Information Administration, Petroleum Supply Annual, DOE/EIA-0340 and Petroleum Supply Monthly, DOE/EIA-0109.

- Finished motor gasoline and blending component stocks.

Energy Information Administration, Petroleum Marketing Annual, DOE/EIA-0487 and Petroleum Marketing Monthly, DOE/EIA-0380.

- Average Crude Oil Refiner's Acquisition C'osts 
Models and Othet:

Energy Information Administration, Short-Term Integrated Forecasting System.

- Forecasts of economic and refinery variables.

General Output Descriptions: MCMM is used to generate very short-term (up to 9 months), monthly forecasts of U.S. demand, price and stock levels of retail motor gasoline.

\section{Computing Environment:}

Hardware I'sed: IBM-compatible personal computer.

Operating System: MS DOS.

Software Used: Micro-TSP, Version 7.01 or higher.

Memory Requirements: $640 \mathrm{~K}$.

Storage Requirements: $640 \mathrm{~K}$.

Estimated Run Time: 30 seconds calculation time on an 80386 PC operating under DOS 5.

Special Features: None.

Independent Expert Reviews: None.

Status of Evaluations by Sponsor: On-going.

\section{References}

J. Cook and C. Shirkey, "A Review of Valdez Oil Market Impacts," Petroleum Marketing Monthly, DOE/EIA-0380 (89/03), March 1989, pp. 5-14.

C. Dahl and T. Sterner, "A Survey of Econometric Gasoline Demand Elasticities," International Journal of Energy Systems, Vol. 11, No. 2, 1991, pp. 73-86.

Energy Information Administration, Short-Term Integrated Forecasting System, 1990 Model Documentation Report, DOE/EIA-M041, 1990, Washington, DC. 


\section{Model Cross Reference}

Equations

(Pages 5-6)

PRICE

DEMAND

DELSTOCK

STOCKTOT

STKCHNG

STOCKDEL

\section{Variable Name}

PRICE

CPI

VMT

RAC87

PPI

STOCKDEL

STKCHNG

DEMAND

IPI

YD

DUMMY

DELSTOCK

STOCKTOT

PRIM_SUP

DAYS

STOCKAVG

\section{Name in Code}

PRICE

CPI

VMT

RAC87

PPI

STOCKDEL

STKCHNG

PS_US

IPI

YD

FEB, MAR, etc.

DELSTOCK

STOCKTOT

PRIM_SUP

DAYS

STOCKAVG

\section{Location in Code \\ (Line Numbers)}

$1-4$

$5-7$

8

9

10

11

\section{Location in Code}

1,4

1,4 (Implicit in PRICE)

1

1

1 (Implicit in RAC87)

$1,2,11$

3,10

5

5

5

$5-7$

8,9

9-11

8

8

11 

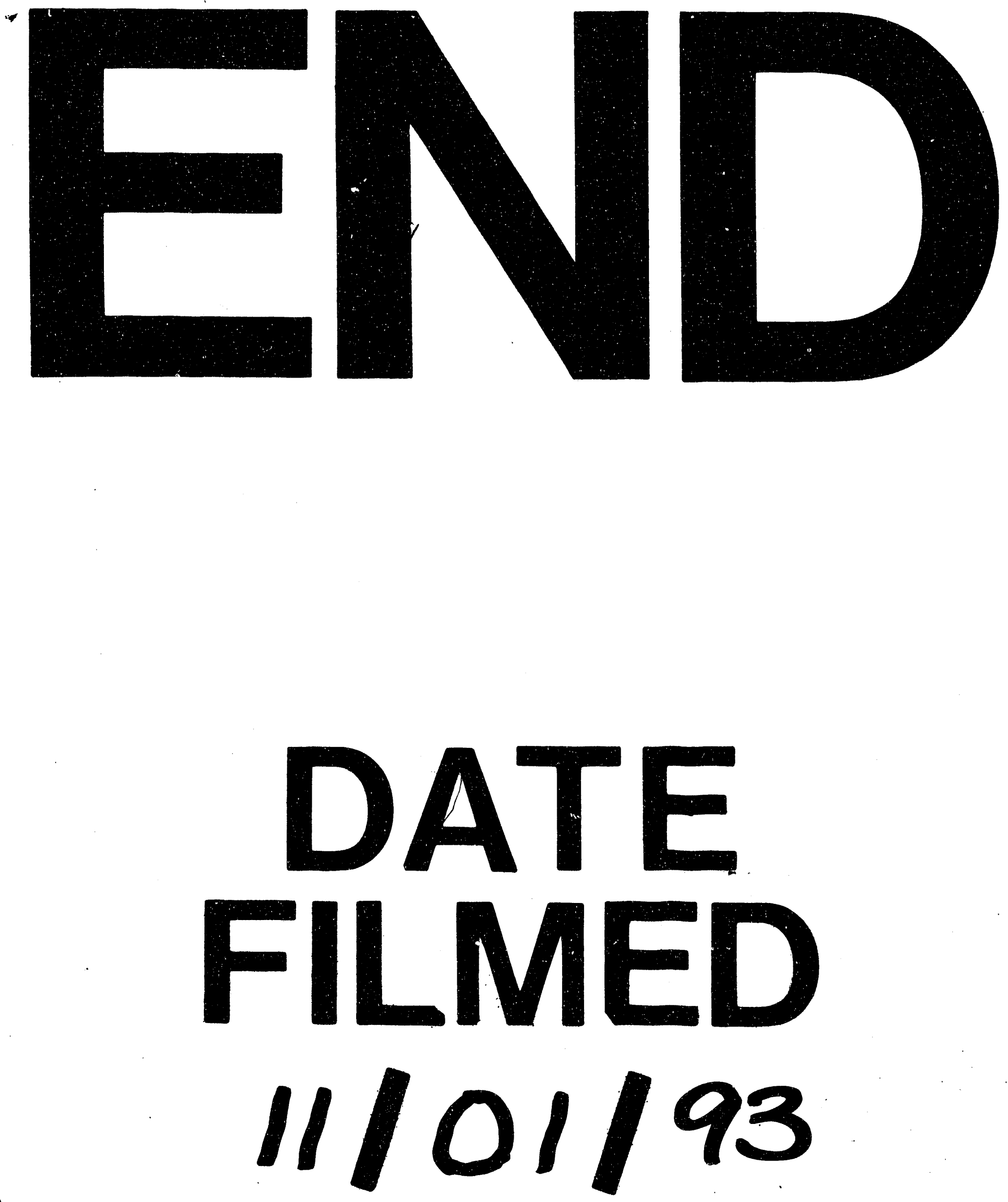

1 
. 